SARA FILIPIAK ๑ https://orcid.org/0000-0001-7818-7168

Instytut Psychologii, Uniwersytet Marii Curie-Skłodowskiej, Lublin Institute of Psychology, Maria Curie-Skłodowska University, Lublin e-mail: s.filipiak@poczta.umcs.lublin.pl

BEATA ŁUBIANKA (1) https://orcid.org/0000-0003-3255-7260

Katedra Psychologii, Uniwersytet Jana Kochanowskiego w Kielcach Department of Psychology, Jan Kochanowski University in Kielce e-mail: blubianka@ujk.edu.pl

\title{
Comparative Analysis of Personality and Preferences of Values of Polish Early Adolescents Learning in Integrated and Non-integrated Classes
}

\begin{abstract}
The aim of the present study was to analyse the personality traits and value preferences of students from integrated and non-integrated classes. Sixty-nine primary school sixth graders were surveyed $(M=12.45 ; S D=.58)$. The group of students attending integrated classes included 38 individuals. The remaining 31 students attended non-integrated classrooms. Personality traits were measured using the Picture-Based Personality Survey for Children (PBPS-C ) and value preferences were determined on the basis of the Picture-Based Value Survey for Children (PBVS-C). The results showed that youth from the integrated classes did not differ significantly from their peers from the non-integrated classes in terms of personality traits. In case of values, students from the non-integrated classes cherished values of Universalism more than their peers from the integrated classes. Correlation analyses showed that the patterns of relations between personality traits and preferred values were partially different for the two groups. Nevertheless, a similar pattern of relations was observed in both groups between Openness to Experience and values in the categories of Self-direction and Universalism.
\end{abstract}

Keywords: personality traits, preference of values, early adolescence, integrated classes, primary school

Słowa kluczowe: cechy osobowości, preferencja wartości, wczesna adolescencja, klasy integracyjne, szkoła podstawowa

\section{INTRODUCTION}

Personality traits and preferences of values are important psychological characteristics that facilitate understanding and predicting human behavior. Despite this fact, research on the comparative studies on the relations between these two variables in early adolescents who learn in integrated and non-integrated classes are scarce (Parks-Leduc, Feldman, Bardi, 2015). The study of personality traits and value systems of young people with and without disabilities allows us to uncover their real needs, beliefs and goals (Resing, Bleichrodt, Dekker, 1999; Pezdek, Doliński, 2010; Recasens, Aponte, 2010). From the practical point of view, investigations in this area enable us to considerably improve methods of teaching and educating young people who attend integrated and traditional classes and to adapt methods to support aspirations of these students 
(Meijer, Soriano, Watkins, 2007). In view of this, we analyzed personality traits, preferred values and the relations between them in students from integrated and non-integrated classes. This article reports the results of a survey conducted among primary school sixth graders from integrated and non-integrated classes in a larger city in eastern Poland. The students were surveyed just before the introduction of a new Polish educational reform which eliminated middle schools and extended primary education from six to eight years. At this critical juncture, it seemed worth comparing the personality traits and the preferred values of students from the two types of classes (integrated vs. non-integrated); both in regard to the developmental changes that take place when children enter adolescence as well as the moment in students' lives when the new reform was introduced.

Development in the period of early adolescence (10/11-14/15 years of age) involves changes in teenagers' overall psychophysical functioning associated with the fact that they have to face up to new roles and social tasks. It is a time of passage from the safety of childhood to the period in which individuals have to take more responsibility for their own lives and set distant goals which they then pursue through their daily activities (Steinberg, 2008). The physical and hormonal changes that the human body experiences in early adolescence draw a clear line between the functioning of a teenager and that of an adult (van Lijenhorst, Crone, 2009). In early adolescence, individuals become more emotionally independent from their parents (Dumontheil, 2015; Steinberg, 2008) which is reflective of the change in the role of family at this stage of life. More than before, adolescents expect their parents to provide support as well as respect the choices they make and the activities they engage in.

\section{EDUCATION IN INTEGRATED CLASSES}

One of the largest reforms in the school systems of the European countries is the introduction of inclusive schooling. All over Europe, the enrol- ment of students with special educational needs (SEN) in inclusive or integrated classrooms is rising and at the same time the proportion of students with SEN in segregated school settings is declining (Schwab, 2018). Integrated and inclusive education (Lindsay, 2007), in which abled and disabled students learn side by side in one classroom, has existed in Poland for nearly 30 years now - although integrated schooling is more common and integrated classes are more numerous than inclusive ones. Both were formally introduced under the Education System Act of 7 September 1991 (Journal of Law of 1991, No. 95, item 425). The idea of inclusive classes is that the students with disabilities learn in a standard class with children without disabilities and follow the same curriculum as their peers. In integrated schooling, disabled students have the opportunity to learn in less numerous classes (max. 15 students; including max. 5 with disabilities) with special regulations (such as the presence of assistant teacher) (Walkowska, Gągorowski, 2014). It might be suggested that current integration model is an introduction to the main idea of a real inclusion or inclusive education (Northway, 1997).

Integrated education emerged as a result of the ideas of social integration being transplanted into the educational ground, where segregated education seemed to be an insufficient solution (Dussan, 2010; Płaczkiewicz, 2020). Integrated education was designed to allow disabled children to study at a school close to their place of residence, so that they could live with their parents on a daily basis, rather than stay at a distant special school and be separated from their family (Sánchez, Carrión, 2010). Another goal of integrated schooling was to give the disabled an opportunity to interact with their typically developing peers and participate in student life on the same terms (Markussen, 2004). In 1996, the European Agency for Development in Special Needs Education was established with a goal of increasing collaboration among various European countries in the area of special education needs (Meijer, Soriano, Watkins, 2007). There are huge variations across the countries in the way they are attempting to implement inclusion as well as unique challenges that each country 
faces (Schwab, 2018). Of course, integrated education has disadvantages such as the lower position of disabled children in class, limited social interactions, greater leniency of teachers, lower educational requirements and teaching programs that are not adapted to the abilities of disabled children (Markussen, 2004; Komorowska, 2005; Domínguez, 2017). On the other hand however, the role of integrated education is to promote responsibility, tolerance and mutual acceptance as well as to protect disabled children from social isolation (Al-Khamisy, 2002; Płaczkiewicz, 2020). Unfortunately, it has been pointed out in the literature that these goals are not always achieved in actual practice (Musselman, Mootilal, MacKay, 1996). Research shows, for example, that deaf early adolescents placed in integrated classes fared worse in interpersonal situations than their hearing peers and deaf boys in mainstream schools were less accepted than their hearing classmates (Wolters, Knoors, Cillessen, Verhoeven, 2011). Research conducted among 138 university students in Spain also showed that university is not always a place fully adjusted for expectations of students with disabilities (Sánchez, Carrión, 2010).

\section{PERSONALITY AND VALUE PREFERENCES OF STUDENTS IN INTEGRATED CLASSES}

Some authors claim that there is a functional similarity between personality traits and values, emphasizing at the same time that they are two separate theoretical constructs characterized by a different organization within the structure of the self (Czerniawska, Dolata, 2005). On the other hand, the two are inseparably connected with each other (Oleś, Płużek, 1990). Both personality traits and values are important components of the self-concept, i.e., the mental representation of the self, which consists of various physical and mental attributes (Kihlstrom, Cantor, 1984). Personality traits - being biological dispositions - affect the way people think, feel, behave (McCrae, Costa, 2008) and interpret the events in which they participate as well as how they see their future. Values which in turn are the product of education and the culture in which one lives, give behaviors a direction consistent with one's motivation and are expressed through preferred ways of achieving the desired goals among others (Rokeach, 1973). Values are beliefs about preferred modes of action and they influence the way a person perceives, interprets and evaluates the situations in which they participate (Schwartz, 1992; Costa, Terraciano, McCrae, 2001). Values are cognitive characteristics but they can also trigger emotions: positive when they are realized, or negative when they cannot be realized (Sheldon, Elliot, 1999).

McCrae and Costa (2008), the authors of the Big Five personality trait model, define personality as a dimension of individual differences related to the traits that are responsible for the characteristic way people feel, think and behave. The authors list five universal personality traits: Extroversion, Neuroticism, Conscientiousness, Agreeableness and Openness to Experience. They view traits as internal dispositions that shape people's self-image and sense of self-efficacy.

Extroversion is associated with seeking social interaction and enjoying the company of others. Neuroticism is related to the traits associated with emotional stability or lack thereof, and it manifests itself in violent and unpredictable responses. Conscientiousness is connected with perseverance at work, patience and the ability to defer gratification. Agreeableness refers to the readiness to join group undertakings and having respect for others. Openness to Experience is associated with the need for change and diversity, as well as such qualities as versatility, ingenuity and the readiness to think and act flexibly (McCrae, Costa, 2008).

An integrated class accommodates abled and disabled children, but above all it is a place of meeting of different personalities (Sandri, 2014). It can be supposed that the experience of learning in an integrated classes can provide a strong stimulus for developing traits that comprise Openness to Experience and Agreeableness. Less numerous classes, a more diverse daily routine, the assistance of a support teacher, and the fact that the young people spend 
several years in this supportive environment are all important factors that mold students' personalities.

There is no systematic research on the personalities of children pursuing the path of integrated education, and the existing studies in this area provide ambiguous results, having been conducted in different paradigms, which means their findings are difficult to compare (Coren, Harlan, 1995; Łubianka, Filipiak, Mariańczyk, 2020). One study of the personality traits of early adolescents learning in integrated classes indicated, among others, that children with moderate reduction in hearing sensitivity did not differ from their normal-hearing peers in terms of Extroversion and Agreeableness. Similarly, a Polish study by Mariańczyk, Łubianka and Filipiak (2019) comparing personality traits of students from integrated and non-integrated classes did not show significant differences in personality traits in Big Five Model. By contrast, a comparative study of personality traits of adolescents with and without visual impairment demonstrated that students with visual impairment were more agreeable compared to their normally sighted peers (Garaigordobil, Bernarás, 2009).

Values are defined as relatively enduring life goals which people hold important and which influence their behavior and moral judgements (Schwartz, 1992). They are organized into a hierarchy, and people differ in their preferences for the particular values. Values guide human life and behavior as well as determine life goals and aspirations. Moreover, as argued by Oleś and Płużek (1990), people are not only capable of choosing the values they want to pursue, but they are also able to reflect on the values they are pursuing. By choosing values from the options the world offers, people create their own lifestyles and give meaning to their lives. The need to find meaning in life and to assign meaning to it is specific to humans. In meeting this need, people pursue the values they hold important, find justification for their own existence, and determine the directions in which to orient their activity.

In his research Korczyński (2009) pointed to the role values play in the adaptation of di- sabled people. Values are shaped in a social setting as part of processes such as socialization or upbringing, which are particularly important with regard to students learning in integrated classrooms. Giryński (1996) showed that young people with mild intellectual disabilities were able to follow socially accepted ethical principles, even though they internalized moral norms more slowly than their typically developing peers. In his study, the 14-19 year olds with intellectual disabilities were found to follow the same values in life as their non-disabled peers. The subjects preferred values such as moral authority, social activity and love, and rejected the values of cynicism and dishonesty. In addition, it was shown that there was a relationship between the preferred values and the subjects' age in the group of teenagers with mild intellectual disability. Younger students chose stability and personal values, and older students chose values related to social activity. Similarly, a study by Bidziński (2010) indicated that physically disabled subjects made comparable value choices to those of their able-bodied peers. The analyses carried out in that study, which traced changes in hierarchy of values of the 15-18-year-olds over the span of 15 years from 1995 to 2010 , showed that youngsters from the beginning of the 21 st century, while compared to their peers from the $1990 \mathrm{~s}$, attributed more importance to individual and competence-related values than to social and moral values. In both of the surveyed groups, there was a decrease in preference for values related to security and world peace over the years and an increase in preference for values related to pleasure, prosperous and adventurous life and accomplishment. The respondents also declared that they cherished the values associated with self-actualization and personal development, at the same time showing a lower preference for interpersonal values related to forgiveness, honesty or politeness. According to Bidziński, the historical context of social and cultural changes had a greater impact on what values the disabled adolescents preferred as they entered the new millennium than the changes related to developmental life stages. 


\section{THE PRESENT STUDY}

There is very little research on the personality traits and values of early adolescents learning in integrated vs. non-integrated settings. Based on the assumptions of the present research project, we formulated the following research questions and hypotheses:

1. Do students from integrated classes differ from students from non-integrated classes in terms of personality traits?

2 . Do students from integrated classes differ from students from non-integrated classes in value preferences?

3. What are the relations between personality traits and preferred values in students from integrated and non-integrated classes?

H1: Students from integrated classes will display higher Agreeableness and Openness to Experience compared to the students from non-integrated classes.

$\mathrm{H} 2$ : Students from integrated classes will show significantly higher appreciation for values related to Security and Benevolence compared to their peers from non-integrated classes. Students from non-integrated classes will prefer values related to Power and Achievement.

H3: There will be relations between Agreeableness, Security and Conformity values and between Openness to Experience and Benevolence in integrated classes. In turn, in non-integrated classes, there will be relations between Extroversion and Achievement as well as Openness to Experience and Self-direction values.

\section{METHOD}

\section{Participants and procedure}

The participants were 69 primary school sixth graders. Thirty-eight ( $44 \%$ of them girls) of them learned in integrated classes. The remaining 31 students (54\% of them girls) learned in non-integrated classes. The mean age of the respondents was $M=12.45$ and the standard deviation was $S D=.58$. Surveys were conduc- ted in four primary schools in Lublin, Poland. Students from seven classes, including three integrated classes, were surveyed. The surveys were carried out between May and June 2018 in keeping with the principles of confidentiality, anonymity and voluntary participation. Initially, a list of public schools and other educational institutions was screened on the website of the Lublin's Board of Education. The list consisted of public primary schools $(\mathrm{N}=37)$, including those with integration units (5) among others. Two schools of each type were randomly selected. It was assumed that in case of the lack of consent from the school head to conduct the research, another random selection will take place (which was not the case). Non-public schools, special schools and special educational centers were not taken into consideration. Students with different disabilities attended integrated classes. They learned together in one class with students without disabilities, which is the main idea of integrated schooling.

The project had been approved by the Research Ethics Committee of Maria Curie-Skłodowska University (No. 29). Consent has been obtained from parents and school headmasters. School psychologists/counsellors have been consulted before the survey was conducted. The questionnaires were administered during one 45-minute class period. The students were informed about the scientific purpose of the survey and that they had the right to refuse to participate without any ramifications.

\section{Measures}

\section{Picture-Based Personality Survey for Children (PBPS-C)}

Personality traits were measured using the Picture-Based Personality Survey for Children (PBPS-C) by Marta Maćkiewicz and Jan Cieciuch (2012). In PBPS-C, personality descriptions are pictorial. PBPS-C consists of 15 items rated on a 5-point scale. The overall score ranges from 3 to 15 points. PBPS-C is available in two versions: for younger children in primary school grades 1 to 3 and for older children in primary school grades 4 to 6 . We used 
the version for older children. This instrument is suited for the cognitive capabilities of persons in late childhood and early adolescence, in whom, according to Piaget's theory (1974), the development of thinking that involves the transition from concrete reasoning to abstract reasoning is underway.

\section{Picture-Based Value Survey for Children (PBVS-C)}

The participants' value preferences were determined using the Picture-Based Value Survey for Children (PBVS-C) (Döring, Blauensteiner, Aryus, Drögenkamp, Bilsky, 2010) adapted into Polish by Cieciuch et al. (2012) and a revised version of this survey, PBVS-Cv2. The PBVS-C is based on Schwartz's theory of universal human values and is used to measure the value systems of children aged 5-13. The questionnaire comprises a manual and an answer sheet with 20 pictures. The pictures show various situations in which the main character finds himself. They represent the 10 categories of values defined in Schwartz's classic value model (1992). Each category is shown in two images. The respondents' task is to assess to what extent the leading character in the picture is similar to them. The assessment is made on a 5-point Likert scale.

\section{Results}

The data we obtained, were interpreted quantitatively using raw scores. The results are discussed in the same order in which the research questions were formulated. We examined personality traits and value preferences of students from integrated and non-integrated classes and the relations between those variables. Normality and homogeneity of variance were tested using the Shapiro-Wilk test and the Levene test. An independent samples $t$-test was used to assess differences in personality traits and preferred values. The effect size was measured using Hedges' $g$ coefficient. Effect size ranges were as follows: .20 to .50 - small effect, .50 to .80 - moderate effect, and above .80 - large effect (Hedges, Olkin, 1985). The relations between personality traits and preferred values were analyzed using the Pearson correlation coefficient $(r)$. Calculations were performed in SPSS 25.

Table 1 compares personality trait scores of students from integrated and non-integrated classes.

Table 1. Descriptive statistics and Student's t-test values for PBPS-C scores of students from integrated and non-integrated classes

Type of class

\begin{tabular}{lcccccc}
\cline { 2 - 5 } Personality trait & \multicolumn{2}{c}{$\begin{array}{c}\text { Integrated } \\
(n=38)\end{array}$} & $\begin{array}{c}\text { Non-integrated } \\
(n=31)\end{array}$ & & \\
& $M$ & $S D$ & $M$ & $S D$ & \\
& & & & & \\
& 11.19 & 2.80 & 12.08 & 2.74 & -1.34 & .186 \\
Extroversion & 8.31 & 3.25 & 8.75 & 2.40 & -.65 & .517 \\
Neuroticism & 8.97 & 2.74 & 8.62 & 2.58 & .54 & .590 \\
Openness to Experience & 9.53 & 2.96 & 10.51 & 2.76 & -1.42 & .158 \\
Conscientiousness & 11.78 & 2.56 & 11.73 & 2.45 & .08 & .932 \\
Agreeableness & & & & & \\
\hline
\end{tabular}


Table 2. Descriptive statistics and Student's t-test for PBVS-Cv2 scores of students from integrated vs. non-integrated classes

\section{Type of class}

\begin{tabular}{|c|c|c|c|c|c|c|}
\hline \multirow[t]{2}{*}{ Value category } & \multicolumn{2}{|c|}{$\begin{array}{l}\text { Integrated } \\
(n=38)\end{array}$} & \multicolumn{2}{|c|}{$\begin{array}{l}\text { Non-integrated } \\
\quad(n=31)\end{array}$} & \multirow[t]{2}{*}{$t(67)$} & \multirow[t]{2}{*}{$p$} \\
\hline & $M$ & $S D$ & $M$ & $S D$ & & \\
\hline Security & 8.50 & 2.58 & 9.59 & 2.13 & -1.93 & .058 \\
\hline Hedonism & 10.16 & 1.30 & 10.41 & 1.55 & -.72 & .476 \\
\hline Self-direction & 8.41 & 1.96 & 8.73 & 2.19 & -.64 & .524 \\
\hline Achievement & 7.78 & 1.75 & 8.62 & 2.26 & -1.70 & .093 \\
\hline Conformity & 6.22 & 2.28 & 6.24 & 1.50 & -.05 & .959 \\
\hline Stimulation & 9.75 & 1.76 & 9.89 & 2.05 & -.31 & .761 \\
\hline Tradition & 8.47 & 2.30 & 8.51 & 2.05 & -.08 & .932 \\
\hline Universalism & 7.09 & 1.87 & 8.16 & 2.14 & -2.19 & .032 \\
\hline Power & 7.41 & 2.73 & 7.05 & 2.17 & .59 & .553 \\
\hline Benevolence & 9.19 & 1.91 & 9.73 & 1.59 & -1.27 & .209 \\
\hline
\end{tabular}

The data presented in table 1 indicate that students who learn in integrated classes do not significantly differ statistically from their peers from non-integrated classes in terms of personality traits.

Table 2 shows the value preferences of students from integrated and non-integrated classes.

Students from non-integrated classes show a significantly higher preference for values from the category of Universalism, compared to their peers from integrated classes $(p<.05)$. Hedges' $g$ effect size is moderate $(g=.53)$.

The results of the correlation analysis between the personality traits and value preferences of students from integrated and non-integrated classes are given in table 3 . 


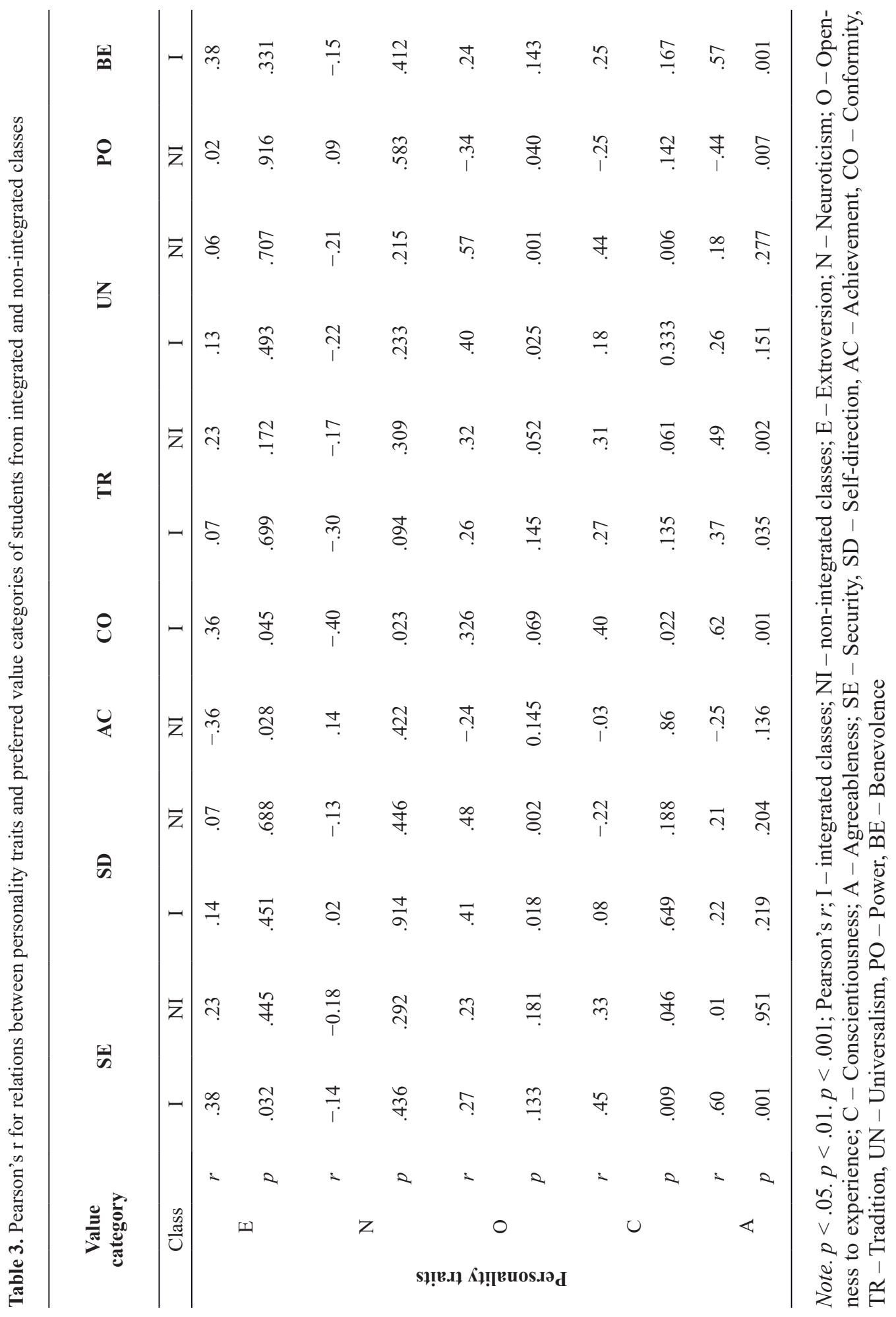


In integrated classes, there are moderate correlations between: Extroversion and value categories of Security and Conformity; Openness to Experience and value categories of Self-direction and Universalism; Conscientiousness and value categories of Security and Conformity and lastly Agreeableness and value categories of Security, Tradition and Benevolence. Negative moderate correlations exist between Neuroticism and Conformity. There is also a strong correlation between Agreeableness and Conformity.

In non-integrated classes there are moderate correlations between: Openness to Experience and values related to Self-direction and Universalism; Conscientiousness and value categories of Security and Universalism and lastly Agreeableness and value of Tradition. Moderate negative correlations are observed between Extroversion and preference for Achievement as well as between both Openness to Experience and Agreeableness and the preference for Power values.

\section{DISCUSSION}

The results obtained in the present study largely confirm previous findings regarding the relations between personality traits and preferred values (Dollinger, Leong, Ulicini, 1996; Sheldon, Elliot, 1999; Parks-Leduc et al., 2015). They also provide novel knowledge on personality traits and value preferences as well as the relations between those variables in students following the integrated and the non-integrated path of education. The comparison of the scores obtained by the sixth graders from integrated and non-integrated classes provides a personality-oriented picture of how the early adolescents function in these two different educational settings. Designed in this way, the study is an attempt to analyze the functioning of integrated classes and to assess the success of integrated education in Poland more generally, with a possible reference to experiences of the other European countries (Lindsay, 2007; Meijer, Soriano, Watkins, 2007; Wiącek, 2008).
The first research question was concerned with differences in personality traits of students from integrated and non-integrated classes. It was expected, in accordance with the idea of integrated education, that students from integrated classes would score higher on Openness to Experience and Agreeableness. The results however, showed no differences in personality traits between the analyzed groups of students, so this hypothesis was not confirmed. This result indicates similarity of the two types of classes in terms of students' personality traits. Probably a small sample size could be a reason for no differences in personality traits or the fact that the two types of classes - integrated and non-integrated - are more similar to each other than it was initially predicted.

The second research question regarded the differences in value preferences in students from integrated and non-integrated classes. Students from integrated classes were expected to show more appreciation for values related to Security and Benevolence compared to their peers from non-integrated classes. By contrast, students from non-integrated classes were expected to prefer values related to Power and Achievement. This hypothesis was not confirmed either. Students from non-integrated classes scored significantly higher on Universalism, which means that compared to their peers from integrated classes, they showed significantly higher appreciation for values related to taking interest in social problems, tolerance and involvement in matters that are important for the common good. One possible explanation for this finding is that students from integrated classes are more focused on meeting their own goals which are important to themselves and people from their closest social network, most commonly their classmates (Komorowska, 2005; Lindsay, 2007; Kołodziejczak, Smoter, 2019). Because they spend much time in an integrated classroom, which is a specific social group, their main motivation may be to get involved in matters and problems they see in their immediate social circle. Preference for Universalism values involves interest in social issues and going 
beyond one's own aspirations and goals (Roccas, Sagiv, Schwartz, Knafo, 2002). These values are cherished more by students from classes with the traditional educational profile. In addition, preference for values of Universalism corresponds well with youthful idealism, which is characteristic of early adolescence. Idealism in this period of life is associated with the particular sensitivity young people have to issues related to justice, tolerance and the good as well as with the fact that they are only starting to gain experience in evaluating how these values are pursued in the surrounding world by both the society and the individuals (Steinberg, 2008).

The last research question regarded the relations between the personality traits and the preferred values of students from integrated and non-integrated classes. It was assumed that these relations would be different for the two groups of students. The results we obtained partially confirmed this hypothesis. Relations between Agreeableness, and values of Security and Conformity in integrated classes were confirmed as well as connections between Extroversion and value of Achievement and Openness to Experience and value of Self-Direction in non-integrated classes. The first result may indicate that positive attitude towards other people and the willingness to cooperate with other students in integrated classes are related to the need to obtain support from others, for example teachers and peers. Harmonious interpersonal relationships provide these students with a sense of security. Concerning the later result obtained in non-integrated classes, one possible explanation stems from the fact that extroverts are sociable and talkative, they are often prone to engage in stimulating experiences and seek for new activities (Aluja, García, García, 2003). They may favor demonstrating competences and abilities in the peer group. Further, Openness to Experience encompasses creativity and divergent thinking (McCrae, Costa, 1997). These traits facilitate higher preferences of values connected with thinking independently and setting life goals in students from traditional path of education.
The results did not confirm the assumption that there will be a relation between Openness to Experience and value of Benevolence in integrated classes as well as that between Openness to Experience and value of Achievement in non-integrated classes. Openness to Experience promotes independent activity and being curious about complex underpinnings of social problems, including problems of other people. One possible explanation is that students from integrated classes expect more support from other people than cherish the welfare of other people. The latter result is difficult to explain as Openness to Experience should facilitate pursuing and realization of important goals among students in non-integrated classes. Maybe students from this type of educational setting are more keen to engage in social activities and focus on being popular in class rather than on pursuit of values encompassed by Achievement category. Affiliation and the need of peer popularity is an important motivator of adolescents' decisions and everyday behaviors (Bruyn, van den Boom, 2005).

Additionally, the results indicated that relations between Extroversion and preferred values differed between the two groups. In integrated classes, Extroversion correlated moderately with Security and Conformity. This means that the willingness to establish and maintain interpersonal relationships in students from those classes was associated with their belief that they were safe and that their social relationships - including their relationships with family and classmates - were stable (Wiącek, 2008). Harmonious interactions with other people based on respect for norms and rules were also important for them. Moderate negative correlations between Extroversion and Achievement values were observed in non-integrated classes. This result shows that the lower the level of traits associated with social involvement, the higher the motivation to succeed and achieve important personal goals.

In both groups surveyed, Conscientiousness correlated moderately with value of Security. The relationship between Conscientiousness and preference for this category of values has been reported in the literature on the subject 
before (Garaigordobil, Bernarás, 2009; Parks-Leduc, Feldman, Bardi, 2015). Perseverance and patience in carrying out one's duties are therefore associated with the motivation to work in a stable and predictable environment. The remaining correlations between Conscientiousness and other values were different in the two groups. In students from non-integrated classes, Conscientiousness correlated moderately with value of Universalism. It can therefore be assumed that the readiness to work persistently and scrupulously in this group of students is associated with the motivation to engage in social matters that go beyond one's own interests and to work toward the common good (Olver, Mooradian, 2003). By contrast, in students from non-integrated classes, Conscientiousness correlated with value of Conformity. This last finding is also supported by previous studies (Parks-Leduc, Feldman, Bardi, 2015). It means that students who are patient and meticulous in doing their duties show the motivation to control themselves. In relation to students from integrated classes, this result may indicate that they work conscientiously in settings in which social principles and norms are respected and in which all members of the group work toward goals that are important to everyone in the group.

In both integrated and non-integrated classes, Agreeableness was moderately correlated with Tradition values. This indicates that in all respondents, focus on cooperation and harmonious coexistence with other people was associated with the desire to maintain customs, traditions and the hierarchy of social relationships (Bardi, Schwartz, 2003). Additionally Agreeableness correlated moderately with Security values and strongly with Conformity values in the group of students from integrated classes. In non-integrated classes, on the other hand, Agreeableness correlated negatively with Power. Similar relations between Agreeableness and the values mentioned above have been described in the literature (Parks-Leduc, Feldman, Bardi, 2015).

The pattern of relationships between Openness to Experience and values of Self-direction and Universalism was comparable in the two groups of students. This means that in all participants, versatility, creativity and readiness to search for novelty and diversity were associated with independent thinking and decision making as well as with tolerance, understanding of others and concern for their welfare. This result is supported by previous studies (Roccass, Sagiv, Schwartz, Knafo, 2002). The negative correlation between Openness to Experience and value of Power in students from non-integrated classes means that high creativity and high desire for change and innovative solutions is associated with a low preference for values related to social recognition, prestige as well as the sense of being important and better than others. This finding is corroborated by data reported by Dollinger et al. (1996). People who are open to new experiences - that is those who are versatile, imaginative, and think outside the box - show little preference for values associated with strengthening their social roles as well as the need for domination and social recognition. Some studies indicate that Openness to Experience is the personality trait that is most closely associated with preferred values (Dollinger et al. 1996). In the present study, Openness to Experience and Agreeableness had the largest number of correlations with values and these were also the strongest correlations. By contrast, Neuroticism was correlated (negatively) with only one value (Conformity) in students from integrated classes. This result also corresponds with findings of well-documented weak associations between Neuroticism and other values in the literature (Parks-Leduc, Feldman, Bardi, 2015). Neuroticism is not likely to facilitate the attainment of the motivational goal of any type of value as being emotionally unstable, anxious and insecure prevents the pursuit of any of the important values (Roccas, Sagiv, Schwartz, Knafo, 2002).

\section{Practical implications}

The results of this study offer insight into the real aspirations of young people. Thus, they provide a ground for developing new and en- 
hancing existing educational methods and adapting them to adolescents' actual needs which are connected with values that they prefer and personality traits that direct their behaviors. The present findings can also be applied in pedagogical and psychological practice, as they indicate the basic directions for future work with students in both regular and integrated classrooms. They show that it is worth to promote educational activities in non-integrated classes that will help students build positive relationships with one another and foster values related to achievement, self-efficacy and ambition. The objective would be to show students that they can achieve important goals while maintaining good relationships with other people. In both groups of students, it is definitely necessary to promote further development of traits related to Openness to Experience and preference of Universalism values such as tolerance and respect for other people's views, acceptance of the multidimensionality of human problems and interest in social issues. The summary of the analyzes above might be guidelines helpful in everyday educational and didactic teaching activities, especially those in integrated classes. It is worth enabling students to discover their strengths and weaknesses in psychosocial functioning and to motivate them to interact with all classmates in different didactic and non-didactic contexts. This could take place during a larger number of advisory hours and workshops conducted more frequently by school psychologists. It is important to apply, for example, the project method based on the joint involvement of all class members more frequently. The desired actions are to sensitize students to the diversity of the environment through applying non-directive teaching model and to practice the ability to deal with various emotionally difficult situations through the use of relaxation and mental trainings.

\section{Limitations and future directions}

The results of this study should be interpreted with caution. This is mainly due to the relati- vely small size of the survey sample. Nevertheless integrated classes are not numerous. We did not take into consideration other variables which may be important and connected with personality traits and values. Despite these shortcomings, findings we report might cast new light on the links between personality traits and preferred values in adolescents pursuing different paths of educations, which is not a popular area of study. Due to a small group, it would be recommended to extend this research onto a bigger sample. It would be also interesting to compare these results with those obtained in other European countries. It could be a crucial basis of making predictions about success of inclusive education, taking into account a cross-cultural context as it would be possible to compare strengths and shortcomings of this type of education in different countries (Meijer, Soriano, Watkins, 2007; Borowska-Beszta, 2014; Rubio, 2017; Kołodziejczyk, Smotner, 2019).

\section{CONCLUSIONS}

The aim of this study was to examine personality traits and value preferences of children pursuing integrated and non-integrated paths of education. Results indicated that students who learn in integrated classes do not significantly differ statistically from their peers from non-integrated classes in terms of personality traits. Moreover, students from non-integrated classes show a significantly higher preference for values from the category of Universalism, compared to their peers from integrated classes. Preference for Universalism values involves interest in social issues and going beyond one's own aspirations. These values are cherished more by students from classes with the traditional educational profile. Results also indicated different correlations between personality traits and preferred values in these two different educational settings. This study, despite its limitations, is an attempt to analyze the functioning of integrated classes and to more generally assess the success of integrated education in Poland. 


\section{REFERENCES}

Al-Khamisy D. (2002), Gotowość nauczycieli do pracy z dziećmi o specjalnych potrzebach edukacyjnych. In: D. Al-Khamisy (Ed.), Integracja społeczna. Praktyczne próby wdrażania (pp. 9-16). Warszawa: Wydawnictwo Akademickie „Żak”.

Aluja A., García O., García L.F. (2003), Relationships among extraversion, openness to experience, and sensation seeking. Personality and Individual Differences, 35(3), 671-680.

Bardi A., Schwartz S.H. (2003), Values and behavior: Strength and structure of relations. Personality and Social Psychology Bulletin, 29(10), 1207-1220.

Bidziński K. (2010), Zmiany w hierarchii wartości deklarowanej przez młodzież niepełnosprawną ruchowo i jej pełnosprawnych rówieśników w latach 1995-2010 jako wyzwanie dla edukacji aksjologicznej. Edukacja, 112(4), 91-103.

Borowska-Beszta B. (2014), A review of lights and shadows of Polish educational integration. International Research Journal for Quality in Education, 1(2), 23-30.

De Bruyn E.H., van den Boom, D. C. (2005), Interpersonal behavior, peer popularity, and self-esteem in early adolescence. Social Development, 14(4), 555-573.

Cieciuch J., Harasimczuk J., Döring A.K. (2012), Structural Validity of the Polish Adaptation of the PictureBased Value Survey for Children. Journal of Psychoeducational Assessment, 31(4), 404-409.

Coren S., Harland R.E. (1995), Personality correlates of variations in visual and auditory abilities. Personality and Individual Differences, 18(1), 15-25. doi:10.1016/0191-8869(94)00133-d.

Costa P.T.Jr., Terracciano A., McCrae R.R. (2001), Gender differences in personality traits across cultures: Robust and surprising findings. Journal of Personality and Social Psychology, 81(2), 322-331. doi: 10.1037/00223514.81.2.322.

Czerniawska M., Dolata E. (2005), Osobowościowe uwarunkowania systemów wartości. Psychologia Rozwojowa, 10(2), 123-133.

Dollinger S.J., Leong F.T., Ulicni S.K. (1996), On traits and values: With special reference to openness to experience. Journal of Research in Personality, 30(1), 23-41. doi: 10.1006/jrpe.1996.0002.

Domínguez A.B. (2017), Educación para la inclusión de alumnos sordos. Revista Latinoamericana de Educación Inclusiva, 45-61.

Döring A.K., Blauensteiner, A., Aryus K., Drögekamp L., Bilsky W. (2010), Assessing values at an early age: The Picture-Based Value Survey for Children (PBVS-C). Journal of Personality Assessment, 92(5), 439-448. doi:10.1080/00223891.2010.497423.

Dumontheil I. (2015), Development of the social brain during adolescence. Psicología Educativa, 21(2), 117-124. doi: 10.1016/j.pse.2015.08.001.

Dussan C.P. (2010), Educación inclusiva: Un modelo de educación para todos. ISEES: Inclusión Social y Equidad en la Educación Superior, 8, 73-84.

Garaigordobil M., Bernarás E. (2009), Self-concept, personality traits and psychopathological symptoms in adolescents with and without visual imxrpairment. The Spanish Journal of Psychology, 12(1). 149-160. doi: $10.1017 / \mathrm{s} 1138741600001566$.

Giryński A. (1996), Świat wartości młodzieży lekko upośledzonej umysłowo. Białystok: Trans Humana.

Hedges L., Olkin I. (1985), Statistical models for meta-analysis. New York: Academic Press.

Journal of Law of 7.09.1991 r. - nr 95 poz. 425. Access: 10.05.2020, http://prawo.sejm.gov.pl/isap.nsf/DocDetails.xsp?id=WDU19910950425.

Kihlstrom J.F., Cantor N. (1984), Mental representations self. In: L. Berkowitz (Ed.), Advances in Experimental Social Psychology (pp. 1-47). San Diego: Academic Press.

Kołodziejczak K., Smoter K. (2019), Integrated Education in Poland-Between the Explicit "Legal"/Legitimate and "Apparent" Dimension. Journal of Vasyl Stefanyk Precarpathian National University, 6(1), 107-112.

Komorowska A. (2005), Kształcenie integracyjne - szansa czy zagrożenie? Kultura i Edukacja, 4, 43-51.

Korczyński M. (2009), Wartości w przystosowaniu osób niepetnosprawnych. Lublin: Wydawnictwo WSSP. Lindsay (2007), Educational psychology and the effectiveness of incusive education/mainstreaming. British Journal of Educational Psychology, 77, 1-24. 
Łubianka B., Filipiak S., Mariańczyk K. (2020), Developmental changes in the locus of control in students attending integrated and non-integrated classes during early adolescence in Poland. Behavioral Sciences, 10(4), 74. doi: 10.3390/bs10040074.

Maćkiewicz M., Cieciuch J. (2012), Jak mierzyć cechy Wielkiej Piątki u dzieci? Prace nad Obrazkowym Pomiarem Cech Osobowości Dzieci (OPCO-D). Psychologia Rozwojowa, 17(3), 69-82.

Mariańczyk K., Łubianka B., Filipiak S. (2019), Integracja na Piątkę? O osobowości uczniów klas integracyjnych i nieintegracyjnych. Języki Obce w Szkole, 1, 55-59.

Markussen E. (2004), Special education: Does it help? A study of special education in Norwegian upper secondary schools. European Journal of Special Needs Education, 19(1), 33-48. doi: 10.1080/08856250 32000167133.

McCrae R.R., Costa P.T.Jr. (1997), Conceptions and correlates of openness to experience. In: R. Hogan, J. Johnson, S. Briggs (Eds.), San Diego: Handbook of personality psychology, 825-847. Academic Press.

McCrae R.R., Costa, P.T.Jr. (2008), The Five-Factor theory of personality. In: O.P. John, R.W. Robins, L.A. Pervin (eds.), Handbook of Personality: Theory and Research (3rd ed., 159-180. New York: Guilford Press.

Meijer C., Soriano V., Watkins A. (2007), Inclusive education across Europe: Reflections upon 10 years of work from the European Agency for Development in Special Needs Education. Childhood Education, 83(6), 361-365.

Musselman C., Mootilal A., MacKay S. (1996), The social adjustment of deaf adolescents in segregated, partially integrated, and mainstreamed settings. The Journal of Deaf Studies and Deaf Education, 1(1), 52-63. doi: 10.1093/oxfordjournals.deafed.a014281.

Northway R. (1997), Integration and inclusion: Illusion or progress in services for disabled people? Social Policy and Administration, 31(2), 157-172. doi:10.1111/1467-9515.00046.

Oleś P., Płużek Z. (1990), Osobowość a system wartości akceptowanych - analiza zależności. Przegląd Psychologiczny, 33, 313-324.

Olver J.M., Mooradian T.A. (2003), Personality traits and personal values: A conceptual and empirical integration. Personality and individual differences, 35(1), 109-125.

Parks-Leduc L., Feldman G., Bardi A. (2015), Personality traits and personal values: A meta-analysis. Personality and Social Psychology Review, 19(1), 3-29. doi: 10.1177/1088868314538548.

Pezdek K., Doliński W. (2010), Teoretyczne i metodologiczne aspekty systemów wartości osób z niepełnosprawnością. Fizjoterapia, 18(4), 60-68.doi: 10.2478/v10109-010-0078-8.

Piaget J. (1974), Understanding causality. New York: Norton.

Płaczkiewicz B. (2020), Inteligencja emocjonalna uczniów klas integracyjnych. Psychologia Rozwojowa, 25(2), 73-86.

Recasens L.T., Aponte C.F. (2010), Uso de perfiles de personalidad para la atención a la diversidad: evidencias en alumnos de educación especial. Educacion y diversidad = Education and diversity: Revista interuniversitaria de investigación sobre discapacidad e interculturalidad, 4(1), 63-72.

Resing W.C.M., Bleichrodt N., Dekker P.H. (1999), Measuring personality traits in classroom. European Journal of Personality, 13(6), 493-509. doi: 10.1002/(SICI)1099-0984(199911/12)13:6<493::AIDPER355>3.0.CO;2-V.

Roccas S., Sagiv L., Schwartz S.H., Knafo A. (2002), The big five personality factors and personal values. Personality and Social Psychology Bulletin, 28(6), 789-801.

Rokeach M. (1973), The Nature of Human Values. New York: The Free Press.

Rubio J.G. (2017), Evolución legislativa de la educación inclusiva en España. Revista de Educación Inclusiva, 10(1), 251-264.

Sánchez A., Carrión J.J. (2010), Los estudiantes con discapacidad en la Universidad de Almería: Ideas y Actitudes sobre su integración Educativa y Social. European Journal of Education and Psychology, 3(2), 329-341. doi:10.1989/ejep.v3i2.72.

Sandri P. (2014), Integration and inclusion in Italy. Towards a special pedagogy for inclusion. Alter, 8(2), 92-104. doi: 10.1016/j.alter.2014.02.004.

Schwab S. (2018), Inclusive and special education in Europe. In: Oxford Research Encyclopedia of Education. doi: 10.1093/acrefore/9780190264093.013.1230. 
Schwartz S.H. (1992), Universals in the content and structure of values: Theoretical advances and empirical tests in 20 countries. In: M.P. Zanna (Ed.), Advances in Experimental Social Psychology, 1-65. San Diego: Academic Press.

Sheldon K.M., Elliot, A.J. (1999), Goal striving, need satisfaction, and longitudinal well-being: The selfconcordance model. Journal of Personality and Social Psychology, 76, 482-497. doi: 10.1037//00223514.76.3.482.

Steinberg L. (2008), Adolescence. New York: McGraw-Hill.

van Lijenhorst L., Crone E. (2009), Het adolescentenbrein: inzichten in risicovol gedrag in de adolescentie uit de cognitieve neurowetenschappen. Neuropraxis, 13(1), 3-7. doi: 10.1007/bf03080140.

Walkowska W., Gągorowski B. (2014), Założenia i bariery kształcenia integracyjnego. In: S. Wrona, W. Walkowska (Eds.), Niepetnosprawność w rodzinie jako wyzwanie edukacyjne, 107-121. Katowice: Wydawnictwo Uniwersytetu Śląskiego.

Wiącek G. (2008), Efektywna integracja szkolna. Lublin: TN KUL.

Wolters N., Knoors H.E.T., Cillessen A.H.N., Verhoeven L. (2011), Predicting acceptance and popularity in early adolescence as a function of hearing status, gender, and educational setting. Research in Developmental Disabilities, 32(6), 2553-2565. doi: 10.1016/j.ridd.2011.07.003.

Kuratorium Oświaty w Lublinie (2018), Wykaz szkół i placówek oświatowych (Access on: 11.03.2018, https:// www.kuratorium.lublin.pl/). 